\title{
Spermatogenez, spermiyogenezis ve klinik yansımaları
}

\section{Spermatogenesis, spermiogenesis and clinical reflections}

\author{
Fuat Kızılay®, Barıș Altay®
}

\section{öz}

Spermatogenez, birçok hormonal ve parakrin faktörle düzenlenen, dinamik bir süreçtir. Bu süreç, otokrin, parakrin ve endokrin etkenlerin güdümünde ve aşamalı bir süreçtir ve gonadotropinlerin etkisi altındadır. Hareketli spermatozoanın meydana geldiği spermiyogenez ise, spermatogenezin nihai basamağıdır. Bu basamakta, Sertoli hücrelerinin önemli bir düzenleyicisi olduğu, hücre-iskeleti yapısı önemlidir. Sertoli hücreleri, germ hücrelerinin gelişimi için destekleyici ortamı sağlarlar ve dinamik bir hücre iskeletine sahiptirler. Gonadotropinler, testosteron, östrojen ve büyüme hormonunun spermatogenezde önemli rolleri vardır ve bunların yokluğunda önemli defektler görülebilmektedir. İnfertilite, yaygın görülen ve çiftlerde önemli psikososyal problemlere neden olan bir problemdir. Azoospermi, erkek faktörünün yaklaşık \%10'undan sorumludur ve bu durumda hormonal tedavinin başarısı sınırlıdır. Bu tedavilerle hedeflenen sonuç, immatür germ hücrelerini, oositi döllemeye yetkin olgun hücreler haline getirmektir. Bu kapsamda, gonadotropinlerin etki mekanizmalarının ve Leydig-Sertoli hücreleri ve germ hücreleri arasındaki etkileşimin aydınlatılması, kritik öneme sahiptir. Spermatogenez basamaklarında rol oynayan lokal ve sistemik faktörlerin daha iyi anlaşılmasıyla ve genetik bazlı farklılıkların ortaya çıkartılmasıyla immatür germ hücrelerinin olgun hücreler haline getirilmesi yoluyla infertilite tedavisinde yeni ufuklar açılabilir.

Anahtar Kelimeler: spermatogenez, infertilite, gonadotropinler, sertoli hücreleri, testosteron

\section{Gíriș}

İnfertilite, çiftlerin \%15-20 kadarında görülmektedir. ${ }^{[1]}$ Vakaların yarısından fazlasında, erkekle ilgili bir faktör bulunmaktadır. ${ }^{[2]}$ Erkeklere bağlı faktörler arasında, vakaların yaklaşı \% 10 'unda non-obstrüktif azoospermi (NOA) mevcuttur. NOA, hem hastalar için en yaygın, hem de doktorlar için en zorlayıcı azoospermi şeklidir, çünkü bu durumda spermatogenezin "geri dönüşümsüz" olduğuna

Ege Üniversitesi Tıp Fakültesi, Üroloji Anabilim Dalı, İzmir, Türkiye

Yazışma Adresi/ Correspondence:

Uzm. Dr. Fuat Kızılay

Ege Üniversitesi Hastanesi Üroloji Anabilim Dalı Bornova/Izmir, Türkiye

Tel. $\quad+902323902500$

E-mail: fuatkizilay@gmail.com

Gelis/ Received: $\quad 30.05 .2019$

Kabul/ Accepted: 10.07.2019

\section{ABSTRACT}

Spermatogenesis is a dynamic process which is managed with various hormonal and paracrine factors. Spermatogenesis is a stepwise process guided by autocrine, paracrine and endocrine factors and is under the influence of gonadotropins. The spermiogenesis, in which the motil spermatozoa occur, is the final step of spermatogenesis. In this step, the cell-skeleton structure, in which the Sertoli cells are important regulators, is fundamental. Sertoli cells provide a supportive environment for the development of germ cells and have a dynamic cytoskeleton. Gonadotropins, testosterone, estrogen and growth hormone have important roles in spermatogenesis and considerable defects may be considered in the absence of these. Infertility is a common problem that causes significant psychosocial challenges in couples. Azoospermia is responsible for approximately $10 \%$ of the male factor and the success of hormonal therapy is limited in this case. The targeted result with these treatments is to transform immature germ cells into mature cells capable of fertilizing oocytes. In this context, the mechanisms of action of gonadotropins and the clarification of the interaction between LeydigSertoli cells and germ cells are critical. With the better understanding of local and systemic factors involved in the spermatogenesis steps and by revealing genetic-based differences, new horizons may be opened in infertility treatment by transforming immature germ cells into mature cells. Keywords: spermatogenesis, infertility, gonadotropins, sertoli cells, testosterone

inanılmaktadır ve hormonal tedavi de dahil olmak üzere herhangi bir tıbbi tedavinin etkisiz kalacağı düşünülmektedir. Oogenezis gibi endokrin regülasyonu hakkında önemli miktarda bilgi bulunan durumların aksine, spermatogenez ile ilgili bilgiler çok sınırlıdır.

İntrasitoplazmik sperm enjeksiyonunun (ICSI) geliştirilmesiyle birlikte mikrodiseksiyon-testiküler sperm ekstraksiyonu (mikro-TESE) ile testisten direkt sperm eldesi ve elde edilen tek bir sperm ile ICSI'yi gerçekleştirmek mümkün olabilmektedir. ${ }^{[3]}$ Ancak bu işlemin başarısız olduğu hastalarda herhangi bir tedavi mümkün olamamaktadır, çünkü bu hastaların testis histopatolojisi sıklıkla matürasyon arresti (MA) ve/veya Sadece Sertoli hücresi "Sertoli cell-only" (SCO) ile uyumlu olmaktadır. NOA patofizyolojisi oldukça heterojen olmakla birlikte, bazı hastalar anti-östrojen, aromataz inhibitörleri ve gonadotropinleri içeren hormonal tedavilere yanıt 
verebilmektedir. Böylece bazı immatür germ hücreleri, geç MA veya hipospermatogenez histopatolojisinde matür hücrelere dönüşebilmektedir. ${ }^{[4]}$

Spermatogenez, Sertoli, Leydig, peritübüler ve germ hücrelerini içeren ve endokrin ve parakrin düzenleyicilerin rol aldığı, kompleks bir süreçtir. Leydig hücrelerini uyaran lütenizan hormon (LH) ve Sertoli hücrelerini uyaran Folikül-Stimülan Hormon (FSH), bu süreçte önemli rol oynarlar. İntratestiküler testosteron üretimi ve spermatogenez, bu iki pitüiter hormonun yönetimindedir. İnterstisiyel boşlukta bulunan Leydig hücreleri, testosteron üretiminden ve seminifer tübüllerde bulunan Sertoli hücreleri, spermatogenezin devamlılı̆̆ ci moleküllerin ve besinlerin üretiminden sorumludur. Testosteron ve FSH, spermatogenezi dolaylı yoldan Sertoli hücreleri üzerinden düzenlerler.

Spermatogenezin hormonal düzenlenmesi, uzun yıllardır bilinen bir konudur. Ancak, özellikle son zamanlarda gonadotropin ve gonadotropin reseptör genlerinin insan mutasyonlarından ve genetiği değiştirilmiş fare modellerinden edinilen genetik bilgiler, spermatogenezin düzenlenmesinde rol oynayan moleküler olaylar hakkındaki bilgilerimizi geliştirmiştir. İnfertilite tedavisinde yeni tedavi yöntemleri geliştirmek ve bunları klinik pratiğe yansıtmak için, Leydig ve Sertoli hücrelerinin ve gonadotropinlerin spermatogenez ve spermiyogenez üzerindeki rolünün anlaşılması ve gonadotropin-bağımlı mekanizmaların net bir şekilde ortaya konulması önem taşımaktadır. Özellikle genetik olarak modifiye edilmiş fare modellerinden elde edilen bazı bilgiler, spermatogenezin hormonal regülasyonunun temel prensiplerini sorgulayarak, patogenetik mekanizmalara $1 s ̧ 1 \mathrm{k}$ tutmakta ve tedavide yeni ipuçları sunmaktadır. Bu derlemede, spermatogenez ve spermiyogenez süreçleri özetlenerek, Leydig ve Sertoli hücrelerinin rollerinin ve gonadotropinlerin spermatogenez üzerindeki etkilerine sşık tutulması amaçlanmıştır.

\section{SPERMATOGENEZ}

Spermatogenez, diploid spermatogonyanın testisin seminifer tübüllerinde haploid spermatozoaya doğru olgunlaştığı ve farklılaştığı, karmaşık ve aşamalı bir olaylar dizisidir. ${ }^{[5]}$ Spermatogonyal kök hücreler kendilerini yenileme ve farklılaşma yetenekleri sayesinde sonuçta haploid yapıda spermatozoa hücresine dönüşür. Bu süreç, insanda ortalama 74 gün devam eden, oldukça kompleks bir süreçtir. ${ }^{[6]}$ Germ hücreler her faz sonrası geliştikçe, seminifer tübüllerin bazal kompartmanından, luminal alana doğru ilerler ve spermatozoa halinde rete testise ulaşır. İntegrin ve aktin bağlantıların bu konuda önemi büyüktür. Sertoli ve somatik hücreler, yapısal ve nutrisyonel desteği spermatogenez boyunca sağlar. Somatik Sertoli hücreleri, seminifer tübüllerde, tübülün tabanından lümenine uzanır ve işlemi kalitatif ve kantitatif olarak destekleyen germ hücre olgunlaşması için bir niş oluştururlar. ${ }^{[5,7-9]}$

Spermatogenik süreç aşamalı bir şekilde gerçekleşir ve otokrin, parakrin ve endokrin hormonal uyarıciların etkileşimi ile düzenlenir. Kaskad, mitotik çoğalma ve yayılma, genetik malzemelerin mayotik rekombinasyonu ve spermatozoanın morfolojik olgunlaşmasını içeren bir dizi hücresel mekanizmayı içerir. ${ }^{[10,11]}$ Spermatogenezin başlaması ve devamlılığı, pitüiter hormonlar olan FSH ve LH'nin kontrolü altındadır.

$\mathrm{Bu}$ işlem, tübüllerin bazal membranına yakın bulunan kök hücrelerin mitotik bölünmesi ile başlar. Bu hücrelere spermatogonyal kök hücre denir. Bunların mitotik bölünmesi iki tür hücre üretir. ${ }^{[12]} \mathrm{A}$ Tipi hücreler kök hücreleri yeniler ve $B$ tipi hücreler, spermatositlere dönüşür. Birincil spermatosit mayoz yoluyla (Mayoz I) iki sekonder sperme bölünür; her sekonder spermatosit, Mayoz II ile iki eşit haploid spermatide bölünür. Spermatidler, spermiyogenez işlemi ile spermatozoaya (sperm) dönüştürülür. Bunlar, sperm hücreleri olarak da bilinen olgun spermatozoalara dönüşür. ${ }^{[13]}$ Böylece, birincil spermatosit, iki hücreye dönüşür; ikincil spermatositler ve bunlar da, alt bölünmeler ile dört spermatozoa ve dört haploid hücreye bölünür.

Spermatogenez sürecinin tamamı, belirli bir hücre tipine karşılık gelen birkaç farklı aşamaya ayrılmaktadır. Tablo 1'de, spermatogenezde ilgili aşamaya giren hücre tipi, kromozom sayısı, DNA kopya numarası/kromatid sayımları ve hücrenin girdiği basamağın adı özetlenmiştir. Sertoli hücre bariyerini geçen spermatogonya progresif motilite kazanır ve geniş primer spermatositleri oluşturmak üzere büyür. Bunların her biri iki sekonder spermatositi oluşturmak üzere mayotik bölünmeye uğrar. Spermatogenezde, spermatogonyal kök hücre havuzundan bazal kompartmanda farklılaşan spermatogonyumların mitoz bölünmelerle amplifikasyonu gerçekleşmekte, sonrasında adlüminal kompartmanda primer ve sekonder spermatositlerden mayoz bölünmelerle haploid hücre oluşumu gerçekleşmektedir. En son olarak, spermiyogenez aşaması ile spermatidler, spermlere evrilmektedir. Spermatositten spermatid evresine geçiş aşamasında spermatositin 46 kromozomu (23 çift kromozom) bölünmektedir, böylece 23 kromozom bir spermatide, diğer 23 kromozom ikinci spermatide gider. Böylece kromozomal genler de bölünür ve fetusun genetik karakterinin yarısı babadan, diğer yarısı anne tarafından sağlanan oositten sağlanır. 
Tablo 1. Spermatogenezde ilgili aşamaya giren hücre tipi, kromozom sayısı, DNA kopya numarası/kromatid sayımları ve hücrelerin girdiği basamaklar

\begin{tabular}{lccc} 
& & \multicolumn{2}{c}{ DNA kopya } \\
Hücre tipi & Ploidi/kromozom sayıları & sayısı/kromozom sayısı & Hücrenin girdiği süreç \\
\hline Spermatogonyum (Ad, Ap ve B tipleri) & Diploid $(2 \mathrm{~N}) / 46$ & $2 \mathrm{C} / 46$ & Spermatositogenez (mitoz) \\
Primer sprematosit & Diploid $(2 \mathrm{~N}) / 46$ & $4 \mathrm{C} / 2 \times 46$ & Spermatidogenez (mayoz I) \\
Iki sekonder sprematosit & Haploid $(\mathrm{N}) / 23$ & $2 \mathrm{C} / 2 \times 23$ & Spermatidogenez (mayoz II) \\
Dört spermatid & Haploid $(\mathrm{N}) / 23$ & $\mathrm{C} / 23$ & Spermiyogenez \\
Dört fonksiyonel spermatozoid & Haploid $(\mathrm{N}) / 23$ & $\mathrm{C} / 23$ & Spermiasyon \\
\hline
\end{tabular}

Spermatogenezis, sürecin doğru bir şekilde gerçekleşmesi için uygun koşulların sağlanmasına bağlıdır ve üremenin devamlılı̆̆ı için gereklidir. DNA metilasyonu ve histon modifikasyonu bu sürecin düzenlenmesinde rol oynamaktadır. ${ }^{[14]}$ Ergenlikle birlikte başlar ve genellikle ölüme kadar kesintisiz devam eder, ancak yaşla birlikte üretilen sperm miktarında hafif bir azalma görülebilir.

\section{SPERMIYOGENEZ}

Spermiyogenez, spermatidlerin olgun, hareketli spermatozoalara doğru olgunlaştığı spermatogenezin son aşamasıdır. Spermatid, bir çekirdek, Golgi aygıtı, sentriol ve mitokondri içeren dairesel bir hücredir. Tüm bu bileşenler spermatozoon oluşumunda rol alır. Mayozun sona ermesinden sonra, haploid yuvarlak spermatitler, bir hücre iskeleti ağ ile küçük, non-polarize hücreler halinde spermiyogenezise girerler. ${ }^{[15]}$ Haploid spermatidler, yeniden yapılanmaya maruz kaldıklarında, bu ağ birden fazla kompleks halinde ve bazı durumlarda, spermatidin yeniden biçimlenmesi ve sperm fonksiyonuna entegre olan benzersiz, iskelet yapıları olarak yeniden düzenlenir.

Spermiyogenez süreci, dört aşamaya ayrılır: golgi aşaması, şapka/akrozom aşaması, kuyruk oluşumu ve olgunlaşma aşaması.

\section{Golgi fazı}

Bu aşamada, çok sayıdaki küçük veziküller içerisinde bulunan granüller, tek büyük bir granül olan akrozomu oluşturmak için birleşirler. ${ }^{[16]}$

Şimdiye kadar çoğunlukla radyal olarak simetrik olan spermatidler polarize olmaya başlarlar. Bir uçta kafa oluşur ve Golgi aygıtı, akrozomu meydana getirecek enzimleri oluşturur. Diğer uçta, mitokondrinin toplandığ 1 ve distal sentriolün bir aksonem oluşturmaya başladığı, kalınlaşmış bir orta parça geliştirir. Spermatid DNA, ayrıca yoğun bir şekilde yoğunlaşarak paketlenmeye başlar. DNA ilk önce spesifik nükleer temel proteinlerle paketlenir, ardından, bunlar, spermatid uzaması sırasında protaminler ile değiştirilir. Elde edilen ve sıkıca paketlenmiş olan kromatin, transkripsiyonel olarak aktif değildir.

\section{Șapka/Akrozom așaması}

$\mathrm{Bu}$ aşamada, akrozomal vezikül, nükleer membran yüzeyi üzerinde büyümeye başlar ve sonuçta nükleer yüzeyin yaklaşık yarısını örter. Proakrozomal veziküller trans-Golgi yığınlarına doğru endofitik yolaklar yardımıyla ilerler, veziküller daha sonra yakınlaşarak nükleer kılıfa doğru ilerler. Golgi aygıtı bundan sonra yerini terk eder, çekirdeğin diğer kutbuna doğru uzaklaşır, ardından, yoğunlaşmış çekirdeği çevreler ve akrozomal şapka haline gelir. Akrozom; hyaluronidaz, asit fosfataz, nöraminidaz ve tripsin benzeri proteaz olan akrozin gibi hidrolitik enzimleri içerir. ${ }^{[17]}$

Spermiyogenezdeki en erken aşamalardan birisi, oosit kümülüs kompleksine sperm penetrasyonu için gerekli enzimlerce zengin olan apikal bir nükleer başlık olan akrozomun oluşumudur. Akrozom oluşumu, pro-akrozomal veziküllerin hem trans-Golgi yığınlarından hem de endositik bir yoldan çekirdeğe aktarımı ile başlar. ${ }^{[18]}$ Bu veziküller, birleşir, yapışır ve nükleer zarf üzerinde hızlıca yayılır. Çeşitli hücre-iskeleti proteinlerinin incelendiği çalışmalarda gösterildiği gibi, akrozom biyogenez ve bütünlüğü, sağlam ve kapsamlı bir hücre-iskeleti ağına dayanır. ${ }^{[19-21]}$

\section{Flagella (kuyruk) olușumu}

$\mathrm{Bu}$ aşamada, hücrenin sentriollerinden birisi, spermin kuyruğu olmak için uzar. Spermiyogenez sırasında oluşan sperm kuyruğu, modifiye, hareketli bir siliumdur. Sperm spesifik aksesuar yapıları (keratin benzeri dış yoğun lifler [ODF], bir mitokondriyal kılıf ve lifli bir kılıf ile uzunluğuna yerleştirilmiş $9+2$ merkezi mikrotübül çekirdeği ve bir aksonomu vardır. Böylece mikrotübüller, flagellanın yapısını ve fonksiyonunu desteklemek için iyi bir şekilde organize olmuştur. Yakın zamanda, F-aktin ve septinlerin önemi vurgulanmıştır. Aksonom oluşumu, sentrozomun hücrenin kaudal kutbuna polarizasyonu ile spermiyogenezde erken dönemde başlatılır. Tipik olarak siliogenezde 
olduğu gibi, spermatid sentrozomu, plazma membranına kenetlenebilen ve bir aksonemi uzatabilen bir bazal gövdeye evrilir. ${ }^{[22]}$

Mikrotübül regülasyonu, muhtemelen kuyruk oluşumuna katkıda bulunmaktadır. Örneğin, mikrotübül parçalayan proteinler, farelerde uygun aksonom oluşumu için gereklidir. ${ }^{[23,24]}$

Spermiyogenez ilerledikçe, spermatid çekirdeği sıkışır ve uzamaya başlar. Spermatid nukleusunun bu yoğun kompaklaşma ve elongasyonu ile beraber distal yarısında manşet formasyonu da eş zamanlı gelişir. ${ }^{[25]}$ Spermiyogenez sonucunda oluşan son ürün olan spermin yapısal özellikleri Tablo 2'de özetlenmiştir.

Tablo 2. Spermin yapısal özellikleri

- Distal parça dışında silindirik yapıda axonemal yapı

- 9 çift mikrotübül A ve B neksin kolları ile bağlanır ve santralda radiyal spoke mevcuttur

- Herbir mikrotübül ODF ile kaplıdır

- Sperm aksonemi oluşturan dış ODF, yoğun miktarda Zn içerir

- Prematür oksidasyonu engeller

- Epididimal geçiş sırasında \%60'dan fazlası atılarak, ODF yapısı daha da sertleşir ve stabilizasyonu sağlar

ODF, outer dense fibers; $Z n$, çinko.

\section{Maturasyon evresi}

$\mathrm{Bu}$ aşamada, rezidüel cisimcikler olarak bilinen fazla sitoplazma, testislerde Sertoli hücreleri tarafindan fagosite edilir. ${ }^{[26]}$

\section{Sertoli hücrelerinin spermatogenezdeki rolü}

Sertoli hücreleri, testiste androjen reseptörleri aracılığıyla testosteron ve dihidrotestosteronun primer hedefidir. ${ }^{[27]}$ Sertoli hücreleri, yapısal ve biyokimyasal olarak olgunlaşan germ hücreleri için destekleyici bir ortam oluşturur. ${ }^{[28]}$ Sertoli hücreleri, ayrıca germ hücreleri için testosteron bağımlı parakrin uyarıcıları salgılar. Ayrıca, FSH reseptörleri yoluyla FSH'nin de hedefindedir; böylece, Sertoli hücreleri, spermatogenezi desteklemek için testosteronun parakrin etkileri ve FSH stimülasyonu ile düzenlenmektedir. ${ }^{[29]}$ Testosteron, spermatogenez için gereken fonksiyonel yolakları başlatmak için Sertoli hücrelerinde androjen reseptörünü (AR) aktive eder. ${ }^{[30]}$ Sertoli hücre sayısı, üretilen sperm miktarını doğrudan belirlemektedir; bir Sertoli hücresi, ancak belirli bir sayıda germ hücresini destekleyebilir. ${ }^{[7,9,31,32]}$

Sertoli hücreleri, seminifer tübüllerin "hemşire” hücreleridir; etkin bir spermatogenez için gerekli yapısal çerçeveyi ve fizyolojik ortamı sağlarlar. ${ }^{[33]} \mathrm{Bu}$ hücreler, seminifer tübülün bazal membranında yerleşmiş, polarize, düzensiz şekilli, kolumnar epitel hücrelerdir. Sertoli hücrelerin bazal yapısı organellerden zengindir, apikal yapısı ise sitoplazmik yapıda gelişen germ hücrelerle ilişkili haldedir. ${ }^{\left[{ }^{[4]}\right.} \mathrm{Bu}$ hücreler, seminifer epitel döngüsü boyunca belirgin dalgalanan bir gen ekspresyon paterni ile bulunur. Bu nedenle, bunların transkriptom profil analizleri, örnek kaynağına, toplama zamanına, kültür koşullarına, uygulanan yaklaşıma, mikro dizi veya transkriptome dizilimine bağlıdır.

Androjen bağlayıcı protein, transferrin, seruloplazmin, plazminojen aktivatörü, TGF-a, TGF- $\beta$, transferrin, IL$1 \alpha$, insülin benzeri büyüme faktörü, inhibin $B$ ve anti-Müllerian hormon dahil olmak üzere spermatogenezi destekleyen Sertoli hücre kaynaklı faktörlerin rolü hakkında çok sayıda çalışma vardır. ${ }^{[35,36]} \mathrm{Bu}$ faktörlerin spermatogenez üzerindeki rollerinin, daha fazla araştırılması gerekmektedir.

Sertoli hücrelerinin bazal bölgeleri, bol miktarda organel içeren "güç merkezleri” dir. Sertoli hücreleri ayrıca, uzun ve apikal sitoplazmik işlemlerle, germ hücrelerinin gelişmesini desteklerler. Hücre iskeleti elemanları ve mitokondri dışında organelleri yoktur. Sertoli hücreleri, germ hücreleri ile birlikte çok sayıda hücre iskeleti-bazlı bağlantıyı devam ettirir ve bu bağlantılar germ hücrelerinin fiziksel olarak bağlı kalmalarını ve spermatidlerin yeniden şekillenmesine katkıda bulunur. Gelişmekte olan germ hücrelerinin yapısal değişikliklerine hareketlerine uyum sağlamak üzere, Sertoli hücre şekli, döngüsel olarak yeniden düzenlenir. Bu işlemlerin devamı için Sertoli hücreleri, aktin filamanlar, mükrotübüller ve ara filamanlardan zengin, dinamik bir hücre iskeletine sahiptir.

\section{Aktin yapıda hücre iskeleti}

Aktin filamanlar, özellikle Sertoli hücrelerinin bazalinde adezyon bileşkelerinin arasında, belirli lokasyonlarda yoğunlaşmıştır. ${ }^{[37]}$ Spermiasyon ve spremiyogenez sırasında ve matür spermatidler Sertoli hücrelerinden salındığı zaman uzarlar. ATP'ye bağlı polimerizasyon yapıda rol oynar. Bu yapı sayesinde Sertoli-germ hücre sıkı bağlantısı, seminifer tübül adluminal bölümünden moleküllerin serbest geçişine engel olur ve immünolojik olarak korunmuş mikroçevre sağlar. [38,39] Ayrıca, kan-testis bariyerini fonksiyonel olarak sağlar.

\section{Ara-filaman yapıda hücre iskeleti}

Yetişkin Sertoli hücrelerinde, ara-filamanlar, yaygın bir sitoplazmik ağ içerisinde yerleşmiştir, bazal olarak yerleşmiş bir çekirdek etrafında dizilmiştir ve plazma membranının 
spesifik bölgelerine doğru ilerlerler. ${ }^{[40,41]}$ Ancak Sertoli hücreleriyle yaygın bir ilişkisi olmasına rağmen, ara-filamanlar, spermatogenez için zorunlu değildir.

\section{Mikrotübül yapıda hücre iskeleti}

Dinamik, polarize hücrelerden beklendiği üzere, Sertoli hücreleri, bol miktarda mikrotübül içeren bir hücre iskeletine sahiptir. ${ }^{[41]}$ Gelişmekte olan germ hücrelerinin ihtiyaçlarına karşılık vermek için Sertoli hücrelerinin ve buna paralel şekilde mükrotübüllerin şekli yeniden düzenlenmektedir. Mikrotübül yeniden şekillenmesindeki en belirgin değişiklikler apikal süreçlerde görülür. ${ }^{[4]]}$ Spermatogonya ve spermatosit hücreleri ile ilgili işlemlerde, mikrotübüller nadir olarak görülür. Aksine, spermatidlerin uzadıkça içerisine gömüldüğü Sertoli hücrelerinin içerisinde bol miktarda bulunurlar. Mikrotübüller, spermatidin uzaması sırasında, akrozomu çevreleyen Sertoli hücrelerinde konsantre hale gelirler ve spermatidin rezidüel sitoplazması ile yakın ilişkili bölgelere doğru uzanım gösterirler.

Farklı aktin, mikrotübül ve ara-filaman temelli yapılar, Sertoli hücresinin germ hücresinin değişen ihtiyaçlarına cevap verdikçe şeklini modifiye etmesini ve eş zamanlı birden çok bölgede hücre içi adezyonları kontrol etmesini sağlarlar. ${ }^{[37]}$ Düzenli aralıklarla kümelenmiş kısa palindromik tekrarlar (CRISPR) gibi teknolojilerin ortaya çıması, muhtemelen öne sürülen birçok mekanizmanın konfirme edilmesi için fonksiyonel verilerin oluşturulmasına da katkıda bulunacaktır. ${ }^{[42]}$

\section{Spermatogenezin hormonal stimülasyonu}

Spermatogenez, başlıca anterior pitüiter bez tarafından salgilanan hormonlar olan LH, FSH ve Leydig hücrelerinden salgilanan testosteronun etkisi altındadır. ${ }^{[43]}$ Ayrıca Sertoli hücrelerinden salgılanan östrojen ve anterior hipofizden salgılanan büyüme hormonu da, spermiyogenez ve testislerin arka plandaki metabolik fonksiyonlarının kontrolü için gereklidir. ${ }^{[4]}$

\section{Testosteronun spermatogenezdeki rolü}

Testosteron, testisin insterstisyumunda yerleşen Leydig hücreleri tarafından salgılanır ve sperm oluşumu için ilk basamak olan testiküler germinal hücrelerin büyümesi ve bölünmesi için gereklidir. ${ }^{[4]}$ Spermatogenez sırasında testosteron bağımlı ana basamak, spermatogenezin son aşaması olan ve spermiyogenez olarak adlandırılan, yuvarlak spermatidlerden uzun spermatidlerin geliştiği post-mayotik aşamadır. ${ }^{[46-}$ 49] Sıçanlarda spermiyogenezin yüksek oranda intratestiküler testosterona bağımlı olduğu gösterilmiştir. ${ }^{[4]}$ Ayrıca intratestiküler testosteron, spermatogenezisin erken bir aşaması olan tip A spermatogonyadan tip B spermatogonyaya dönüşüm için gereklidir. ${ }^{\left[{ }^{[6]}\right]}$ Testosteronun spermatogonyal proliferasyondaki rolü muhtemelen kısıtlıdır ancak ${ }^{[50-51]}$ anti-apoptotik mekanizmalarla spermatositlerin ve spermatidlerin sağkalımında etkili olduğu gösterilmiştir. ${ }^{[22]}$

\section{Lüteinizan hormonun spermatogenezdeki rolü}

Anterior pitüiter bez tarafından salgılanan LH, Leydig hücrelerini testosteron salgilamak üzere stimüle eder. Leydig hücreleri, seminifer tübüllerin dışarısında yer almakta ve LH reseptörleri taşımaktadır. Yakın zamanda, LH reseptörü $\mathrm{KO}(\mathrm{LuRKO})$ ve testosteron ile tedavi edilen LuRKO farelerinin testis dokusunun transkriptom analizi, LH eylemlerinin yokluğunda testiste gen ekspresyonundaki kusurların çoğunun, testosteron replasmanı ile büyük ölçüde düzeltildiğini göstermiştir. ${ }^{[53]}$

Uzun süredir FSH'nin spermatogenez için LH'den daha önemli bir faktör olduğuna inanılyyordu. Ancak, LuRKO farelerinden elde edilen bulgular, LH'nin spermatogenez için önemini ortaya koydu. Bununla birlikte, spermatogenez için baskın olan gonadotropin bilgisi, FSH'den LH'ye doğru kaymıştır. ${ }^{[54]}$

\section{Folikül-Stimülan Hormonun spermatogenezdeki rolü}

Anterior pitüiter bez tarafından salgılanan FSH, Sertoli hücrelerini stimüle eder. Bu stimülasyon olmadan spermatidlerin sperme dönüşümü (spermiyogenez süreci) olmayacaktır. Seminifer tübüllerde yerleşen Sertoli hücreleri, FSH ve testosteronun etkisi altında spermatogenezi destekler. Daha önce bahsedildiği üzere spermatogenezin baskın hormonal kontrolü bilgisi FSH'den LH'ye doğru kaymış olsa $\mathrm{da}^{[54]} \mathrm{FSH}$, spermatogenezin başlatılması ve spermatogenezin kalitatif ve kantitatif olarak devamı için gereklidir. ${ }^{[55]} \mathrm{FSH}$, tek başına spermatogenez için gerekli değildir ve FSH'nin esas rolü intratestiküler testosteron ile birlikte üretilen spermin kalitesini artırmaktır. ${ }^{[56]}$

FSH, Sertoli hücrelerinin prenatal ve prepubertal proliferasyonunu uyarır ve nihai hücre sayılarını belirler ve bu hücreler, seminifer tübül ve testislerin boyutunu etkiler. FSH, spermatogonya ve preleptoten spermatositlerinde mitotik ve mayotik DNA sentezini uyarır ve Sertoli hücrelerine etki ederek bu premayotik germ hücreleri için bir sağkalım faktörü olarak etki eder. ${ }^{[57]} \mathrm{FSH}$, bu ön basamakları indükleyerek, mayozu dolaylı yoldan uyarır ve spermatogenezi düzenler. 


\section{Diğer hormonların spermatogenezdeki rolü}

Östrojenler, FSH etkisi ile Sertoli hücreleri tarafından testosterondan oluşturulur ve spermiyogenez için gereklidirler. ${ }^{[8]}$ Büyüme hormonu, testislerin arka plandaki metabolik fonksiyonlarının kontrolü için gereklidir (diğer vücut hormonları gibi). ${ }^{[59]}$ Büyüme hormonu, özellikle spermatogonyanın erken bölünmesini indükler ve yokluğunda ortaya çıkan spermatogenez defekti, infertiliteye yol açabilir. ${ }^{[60]}$

\section{Sonuç ve gelecekteki klinik uygulamalar}

Spermatogenez, testiküler seminifer tübüllerde diploid spermatogonyanın haploid spermatazoaya evrildiği dinamik bir süreçtir. Aynı zamanda, hormonal, parakrin ve psikolojik birçok faktörün etkisinde olan ve hala aydınlatılması gereken birçok hususu barındıran kompleks olaylar dizisidir. Sertoli hücreleri, germ hücrelerinin olgunlaşması için destekleyici bir ortam oluşturmakta, aynı zamanda bu hücrelere parakrin faktörler ve destek sağlamaktadır. Germ ve Sertoli hücre ilişkisinde rol oynayan etkenler daha net aydınlatılmalıdır. Böylece, germ hücrelerinin gelişmelerine Sertoli hücreleri üzerinden nasıl katkıda bulunabileceği konusunda faydalı bilgiler elde edilebilinir. Leydig/Sertoli hücreleri ve germ hücreleri arasındaki etkileşimle ilgili bilgiler hala sınırlıdır ve üreme teknolojilerindeki gelişmelerle birlikte daha fazla araştırılmalıdır. Hormonal tedavi deneyiminden elde edilen bilgiler ve erkek üreme endokrinolojisine ilişkin diğer temel bilgiler azoospermiye karşı yeni hormonal tedaviler oluşturmak için yeni bir pencere açabilecektir.

Azoospermi ile prezente olan vakalarda mikro-TESE ile sperm elde etme oranı deneyimli merkezlerde dahi vakaların yarısıyla sınırlıdır. Bu işlemle sperm elde etmenin mümkün olmadığı hastalarda günümüz için önerilebilen etkin bir tedavi bulunmamaktadır, çünkü bu hastaların testis hitopatolojisi sıklıkla MA veya SCO ile uyumludur. $\mathrm{Bu}$ heterojen hasta grubu için anti-östrojenler ve aromataz inhibitörleri gibi bazı hormonal manüpilasyonlar, kısıtlı etkileri ile mevcuttur. Bu vakalardaki immatür hücrelerin gelişmesinde rol oynayan endokrin ve parakrin faktörlerin aydınlatılması ile, özellikle geç MA ve hipospermatogenez histopatolojisindeki hastalarda matür spermatazoa eldesi için umut veren gelişmeler olabilir. Spermatogenez üzerindeki hormonal etkiler, MA ile karşımıza gelen mikro-TESE ile sperm elde edilemeyen hastalarda alternatif çözümlere ışık tutabilir.

Gonadotropinler (LH ve FSH), Leydig ve Sertoli hücrelerini uyararak spermatogenezde önemli rol oynarlar. $\mathrm{Bu}$ hormonlarin normal ve patolojik durumlarda spermatogenez üzerindeki etkilerini anlamak, kusurlu spermatogenezi indüklemek için innovatif bir gonadotropin tedavisi geliştirmek için oldukça kritiktir. Spermatogenez aşamalarının daha iyi anlaşılmasıyla birlikte bunlara ait gelişmeler, erkek infertilitesinde kliniğe ait çözümlere yol gösterici olacaktır.

Ayrıca, genetik faktörlere bağlı olarak bazı hasta gruplarının gonadotropin tedavilerine daha fazla yanıt verebileceği gösterilmiştir. ${ }^{[61,62]}$ Hastaların genetik zeminlerinin ve hetero-, homozigot polimorfizmlerinin araştırılması da, tedavi etkinliğine sşık tutacak diğer bir konudur.

Hakem Değerlendirmesi

Dış bağımsız

Çıkar Çatışması

Yazarlar çıkar ilişkisi olmadığını beyan etmişlerdir.

Finansal Destek

Herhangi bir mali destek alınmamıştır.

Peer-review

Externally peer-reviewed.

Conflict of Interest

No conflict of interest was declared by the authors.

Financial Disclosure

No financial disclosure was received.

\section{REFERANSLAR}

1. Cao XW, Lin K, Li CY, Yuan CW. [A review of WHO Laboratory Manual for the Examination and Processing of Human Semen (5th edition)]. Zhonghua Nan Ke Xue 2011;17:1059-63.

2. Kumar N, Singh AK. Trends of male factor infertility, an important cause of infertility: A review of literature. J Hum Reprod Sci 2015;8:191-6. [CrossRef]

3. Schlegel PN. Testicular sperm extraction: microdissection improves sperm yield with minimal tissue excision. Hum Reprod 1999; 14:131-5. [CrossRef]

4. Shiraishi K. Hormonal therapy for non-obstructive azoospermia: basic and clinical perspectives. Reprod Med Biol 2015;14:65-72. [CrossRef]

5. Mruk DD, Cheng CY. The Mammalian Blood-Testis Barrier: Its Biology and Regulation. Endocr Rev 2015;36:564-91. [CrossRef]

6. Amann RP. The cycle of the seminiferous epithelium in humans: a need to revisit? J Androl 2008;29:469-87. [CrossRef]

7. Griswold MD. The central role of Sertoli cells in spermatogenesis. Semin Cell Dev Biol 1998;9:411-6. [CrossRef]

8. Sharpe RM. Sperm counts and fertility in men: a rocky road ahead. Science \& Society Series on Sex and Science. EMBO Rep 2012;13:398-403. [CrossRef]

9. Sharpe RM, McKinnell C, Kivlin C, Fisher JS. Proliferation and functional maturation of Sertoli cells, and their relevance to disorders of testis function in adulthood. Reproduction 2003;125:769-84. [CrossRef]

10. Ehmcke J, Hubner K, Scholer HR, Schlatt S. Spermatogonia: origin, physiology and prospects for conservation and manipulation of the male germ line. Reprod Fertil Dev 2006;18:7-12. [CrossRef]

11. Jan SZ, Hamer G, Repping S, de Rooij DG, van Pelt AM, Vormer TL. Molecular control of rodent spermatogenesis. Biochim Biophys Acta 2012;1822:1838-50. [CrossRef]

12. Zhou Q, Wang M, Yuan Y, Wang X, Fu R, Wan H, et al. Complete Meiosis from Embryonic Stem Cell-Derived Germ Cells In Vitro. Cell Stem Cell 2016;18:330-40. [CrossRef] 
13. Sharma S, Hanukoglu A, Hanukoglu I. Localization of epithelial sodium channel $(\mathrm{ENaC})$ and CFTR in the germinal epithelium of the testis, Sertoli cells, and spermatozoa. J Mol Histol 2018;49:195-208. [CrossRef]

14. Song N, Liu J, An S, Nishino T, Hishikawa Y, Koji T. Immunohistochemical Analysis of Histone H3 Modifications in Germ Cells during Mouse Spermatogenesis. Acta Histochem Cytochem 2011;44:183-90. [CrossRef]

15. Griswold MD. Spermatogenesis: The Commitment to Meiosis. Physiol Rev 2016;96:1-17. [CrossRef]

16. Kimura M, Takagi S, Nakashima S. Aurora A regulates the architecture of the Golgi apparatus. Exp Cell Res 2018;367:73-80. [CrossRef]

17. Muciaccia B, Boitani C, Berloco BP, Nudo F, Spadetta G, Stefanini $\mathrm{M}$, et al. Novel stage classification of human spermatogenesis based on acrosome development. Biol Reprod 2013;89:60. [CrossRef]

18. Elkis Y, Bel S, Rahimi R, Lerer-Goldstein T, Levin-Zaidman S, Babushkin T, et al. TMF/ARA160 Governs the Dynamic Spatial Orientation of the Golgi Apparatus during Sperm Development. PLoS One 2015;10:e0145277. [CrossRef]

19. Vogl AW. Distribution and function of organized concentrations of actin filaments in mammalian spermatogenic cells and Sertoli cells. Int Rev Cytol 1989;119:1-56. [CrossRef]

20. Moreno RD, Palomino J, Schatten G. Assembly of spermatid acrosome depends on microtubule organization during mammalian spermiogenesis. Dev Biol 2006;293:218-27. [CrossRef]

21. Shen J, Chen W, Shao B, Qi Y, Xia Z, Wang F, et al. Lamin A/C proteins in the spermatid acroplaxome are essential in mouse spermiogenesis. Reproduction 2014;148:479-87. [CrossRef]

22. Lehti MS, Sironen A. Formation and function of the manchette and flagellum during spermatogenesis. Reproduction 2016;151:R4354. [CrossRef]

23. O'Donnell L, Rhodes D, Smith SJ, Merriner DJ, Clark BJ, Borg C, et al. An essential role for katanin p80 and microtubule severing in male gamete production. PLoS Genet 2012;8:e1002698. [CrossRef]

24. Dunleavy JEM, Okuda H, O'Connor AE, Merriner DJ, O’Donnell L, Jamsai D, et al. Katanin-like 2(KATNAL2) functions in multiple aspects of haploid male germ cell development in the mouse. PLoS Genet 2017;13:e1007078. [CrossRef]

25. Kierszenbaum AL, Tres LL. The acrosome-acroplaxome-manchette complex and the shaping of the spermatid head. Arch Histol Cytol 2004;67:271-84. [CrossRef]

26. Yoshinaga K, Toshimori K. Organization and modifications of sperm acrosomal molecules during spermatogenesis and epididymal maturation. Microsc Res Tech 2003;61:39-45. [CrossRef]

27. Silva FR, Leite LD, Wassermann GF. Rapid signal transduction in Sertoli cells. Eur J Endocrinol 2002;147:425-33. [CrossRef]

28. Crisostomo L, Alves MG, Gorga A, Sousa M, Riera MF, Galardo MN, et al. Molecular Mechanisms and Signaling Pathways Involved in the Nutritional Support of Spermatogenesis by Sertoli Cells. In: Alves M., Oliveira P. (eds) Sertoli Cells. Methods in Molecular Biology, vol 1748. Humana Press, New York, NY; 2018. [CrossRef]

29. Shiraishi K, Matsuyama H. Gonadotoropin actions on spermatogenesis and hormonal therapies for spermatogenic disorders [Review]. Endocr J 2017;64:123-31. [CrossRef]

30. Welsh M, Saunders PT, Atanassova N, Sharpe RM, Smith LB. Androgen action via testicular peritubular myoid cells is essential for male fertility. FASEB J 2009;23:4218-30. [CrossRef]

31. Abel MH, Baker PJ, Charlton HM, Monteiro A, Verhoeven G, De Gendt K, et al. Spermatogenesis and sertoli cell activity in mice lacking sertoli cell receptors for follicle-stimulating hormone and androgen. Endocrinology 2008;149:3279-85. [CrossRef]
32. Clermont Y, Perey B. Quantitative study of the cell population of the seminiferous tubules in immature rats. Am J Anat 1957;100:241-67. [CrossRef]

33. Dunleavy JEM, O'Bryan M, Stanton PG, O’Donnell L. The Cytoskeleton in Spermatogenesis. Reproduction 2019;157:R5372. [CrossRef]

34. Franca LR, Hess RA, Dufour JM, Hofmann MC, Griswold MD. The Sertoli cell: one hundred fifty years of beauty and plasticity. Andrology 2016;4:189-212. [CrossRef]

35. Alves MG, Rato L, Carvalho RA, Moreira PI, Socorro S, Oliveira PF. Hormonal control of Sertoli cell metabolism regulates spermatogenesis. Cell Mol Life Sci 2013;70:777-93. [CrossRef]

36. Luca G, Baroni T, Arato I, Hansen BC, Cameron DF, Calafiore R. Role of Sertoli Cell Proteins in Immunomodulation. Protein Pept Lett 2018;25:440-5. [CrossRef]

37. Vogl W, Lyon K, Adams A, Piva M, Nassour V. The endoplasmic reticulum, calcium signaling and junction turnover in Sertoli cells. Reproduction 2018;155:R93-R104. [CrossRef]

38. Mital P, Hinton BT, Dufour JM. The blood-testis and bloodepididymis barriers are more than just their tight junctions. Biol Reprod 2011;84:851-8. [CrossRef]

39. Kaur G, Thompson LA, Dufour JM. Sertoli cells -immunological sentinels of spermatogenesis. Semin Cell Dev Biol 2014;30:36-44. [CrossRef]

40. Amlani S, Vogl AW. Changes in the distribution of microtubules and intermediate filaments in mammalian Sertoli cells during spermatogenesis. Anat Rec 1988;220:143-60. [CrossRef]

41. Vogl AW, Vaid KS, Guttman JA. The Sertoli cell cytoskeleton. Adv Exp Med Biol 2008;636:186-211. [CrossRef]

42. Peters JM, Colavin A, Shi H, Czarny TL, Larson MH, Wong S, et al. A Comprehensive, CRISPR-based Functional Analysis of Essential Genes in Bacteria. Cell 2016;165:1493-506. [CrossRef]

43. Corradi PF, Corradi RB, Greene LW. Physiology of the Hypothalamic Pituitary Gonadal Axis in the Male. Urol Clin North Am 2016;43:151-62. [CrossRef]

44. Tatem AJ, Beilan J, Kovac JR, Lipshultz LI. Management of Anabolic Steroid-Induced Infertility: Novel Strategies for Fertility Maintenance and Recovery. World J Mens Health 2019;37:e16. [CrossRef]

45. Wen Q, Cheng CY, Liu YX. Development, function and fate of fetal Leydig cells. Semin Cell Dev Biol 2016;59:89-98. [CrossRef]

46. McLachlan RI, O’Donnell L, Meachem SJ, Stanton PG, de Kretser DM, Pratis K, Robertson DM. Identification of specific sites of hormonal regulation in spermatogenesis in rats, monkeys, and man. Recent Prog Horm Res 2002;57:149-79. [CrossRef]

47. Singh J, O'Neill C, Handelsman DJ. Induction of spermatogenesis by androgens in gonadotropin-deficient (hpg) mice. Endocrinology 1995;136:5311-21. [CrossRef]

48. Allan CM, Garcia A, Spaliviero J, Zhang FP, Jimenez M, Huhtaniemi I, Handelsman DJ. Complete Sertoli cell proliferation induced by follicle-stimulating hormone (FSH) independently of luteinizing hormone activity: evidence from genetic models of isolated FSH action. Endocrinology 2004;145:1587-93. [CrossRef]

49. Matthiesson KL, McLachlan RI, O’Donnell L, Frydenberg M, Robertson DM, Stanton PG, Meachem SJ. The relative roles of follicle-stimulating hormone and luteinizing hormone in maintaining spermatogonial maturation and spermiation in normal men. J Clin Endocrinol Metab 2006;91:3962-9.

50. Haywood M, Spaliviero J, Jimemez M, King NJ, Handelsman DJ, Allan CM. Sertoli and germ cell development in hypogonadal (hpg) mice expressing transgenic follicle-stimulating hormone alone or in combination with testosterone. Endocrinology 2003;144:509-17. [CrossRef] 
51. Holdcraft RW, Braun RE. Hormonal regulation of spermatogenesis. Int J Androl 2004;27:335-42. [CrossRef]

52. Ruwanpura SM, McLachlan RI, Meachem SJ. Hormonal regulation of male germ cell development. J Endocrinol 2010;205:117-31. [CrossRef]

53. Griffin DK, Ellis PJ, Dunmore B, Bauer J, Abel MH, Affara NA. Transcriptional profiling of luteinizing hormone receptor-deficient mice before and after testosterone treatment provides insight into the hormonal control of postnatal testicular development and Leydig cell differentiation. Biol Reprod 2010;82:1139-50. [CrossRef]

54. Huhtaniemi I. A short evolutionary history of FSH-stimulated spermatogenesis. Hormones (Athens) 2015;14:468-78. [CrossRef]

55. Nieschlag E, Simoni M, Gromoll J, Weinbauer GF. Role of FSH in the regulation of spermatogenesis: clinical aspects. Clin Endocrinol (Oxf) 1999;51:139-46. [CrossRef]

56. Kato Y, Shiraishi K, Matsuyama H. Expression of testicular androgen receptor in non-obstructive azoospermia and its change after hormonal therapy. Andrology 2014;2:734-40. [CrossRef]

57. de Kretser DM, Loveland KL, Meinhardt A, Simorangkir D, Wreford N. Spermatogenesis. Hum Reprod 1998;13 Suppl 1:1-8. [CrossRef]
58. Schulster M, Bernie AM, Ramasamy R. The role of estradiol in male reproductive function. Asian J Androl 2016;18:435-40. [CrossRef]

59. Wagner MS, Wajner SM, Maia AL. The role of thyroid hormone in testicular development and function. J Endocrinol 2008;199:35165. [CrossRef]

60. Gandhi J, Hernandez RJ, Chen A, Smith NL, Sheynkin YR, Joshi G, Khan SA. Impaired hypothalamic-pituitary-testicular axis activity, spermatogenesis, and sperm function promote infertility in males with lead poisoning. Zygote 2017;25:103-10. [CrossRef]

61. Simoni M, Santi D, Negri L, Hoffmann I, Muratori M, Baldi E, et al. Treatment with human, recombinant FSH improves sperm DNA fragmentation in idiopathic infertile men depending on the FSH receptor polymorphism p. N680S. a pharmacogenetic study. Hum Reprod 2016;31:1960-9. [CrossRef]

62. Selice R, Garolla A, Pengo M, Caretta N, Ferlin A, Foresta C. The response to FSH treatment in oligozoospermic men depends on FSH receptor gene polymorphisms. Int J Androl 2011;34:306-12. [CrossRef] 